\title{
Strategic Hypocrisy: The British Imperial Scripting of Tibet's Geopolitical Identity
}

\section{DIBYESH ANAND}

The protests in and around Tibet in 2008 show that Tibet's status within China remains unsettled. The West is not an outsider to the Tibet question, which is defined primarily in terms of the debate over the status of Tibet vis-à-vis China. Tibet's modern geopolitical identity has been scripted by British imperialism. The changing dynamics of British imperial interests in India affected the emergence of Tibet as a (non)modern geopolitical entity. The most significant aspect of the British imperialist policy practiced in the first half of the twentieth century was the formula of "Chinese suzerainty/Tibetan autonomy." This strategic hypocrisy, while nurturing an ambiguity in Tibet's status, culminated in the victory of a Western idea of sovereignty. It was China, not Tibet, that found the sovereignty talk most useful. The paper emphasizes the worldconstructing role of contesting representations and challenges the divide between the political and the cultural, the imperial and the imaginative.

$\mathrm{H}$ OW DOES A PLACE acquire geopolitical identity? The answer is not selfevident. The status of a geopolitical entity is not simply reflective of a pre-given reality. The relational and processual nature of identity, studied extensively in the context of the individual and the collective, holds true for geopolitical constructs, too. This paper is an analysis of one such entity-“Tibet." The Seventeen-Point Agreement signed by the Tibetan government and the People's Republic of China (PRC) in 1951 concretized Chinese sovereignty over Tibet in writing. Even though the Dalai Lama later renounced the treaty after fleeing from Tibet in 1959 and there have been numerous protests against Chinese rule by Tibetans (the March 2008 protests are a recent example), no country in the world recognizes the Dalai Lama's government in exile as a legitimate government and no one denies Chinese sovereignty explicitly. This paper focuses on the period before this authoritative scripting of sovereignty as the defining term in Sino-Tibetan relations. Instead of adhering to the widespread emphasis on Sino-Tibetan conflict, the paper will analyze the role of British imperialism in fixing Tibet's geopolitical identity.

The Tibet question (see Sautman and Dreyer 2006) is about the struggle over what "Tibet" was, is, and should be, and the protests of 2008 once again brought the 
issue into the limelight. Was Tibet once an independent state, or was it always an integral part of China? Is Tibet an occupied country, or is it a backward part of China benefiting from civilizing modernization under the aegis of Chinese state? Should Tibet be an entity based on the exercise of the right of self-determination by Tibetans, or should Tibet always be China's Tibet? A crucial, often neglected, ingredient in the mix of the Tibet question is the West, both as a political actor and as a source of ideas that have shaped the contemporary world. This paper analyses the British imperial scripting of Tibet in terms of sovereignty and the facilitative role played by Western representations of Tibet in it (for a wider discussion of the subject, see Anand 2007, 2008). While some historians have studied the modern history of Tibet in the context of British imperialism (McKay 1997; Mehra 1979; Palace 2005), and others have charted the history of the Western imagination of Tibet (Bishop 1989, 1993; Dodin and Räther 2001; Klieger 1997; Lopez 1998), few have attempted to seriously link the imaginative and the imperial as mutually reinforcing (for an exception, see Bishop 1989). The scripting of the geopolitical identity of Tibet in terms of sovereignty, suzerainty, autonomy, and independence can only be understood within the British imperial legacy.

I focus on this tale in order to challenge the divide between the political and the cultural, to assert the salience of cultural imaginations as political practices, to highlight the arbitrariness of contemporary international relations, and to argue that sovereignty is not a settled fact but an ever changing, always open, contested fiction. Conceptualizing sovereignty as a fiction opens up the realm of the political to multiple possibilities and thus poses problems of international politicssuch as the Tibet question-not as intractable but as made so because of a buying into of sovereignty talk as sacrosanct. It thus challenges Melvyn C. Goldstein's widely accepted argument that the "Tibet question- the political status of Tibet vis-à-vis China_is an intractable nationalistic conflict” (1995, 3).

\section{Sovereignty TALK}

In a certain sense, the Tibet question is a nonstarter, for all of the nationstates have agreed to the answer: China has sovereignty over Tibet. So Tibet does not exist as an independent geopolitical entity but is an "integral part" of a powerful member of the international community that is a club of nation-states only. The sacrosanct principle that is marshaled by China and accepted by all states in the world to designate Sino-Tibetan relations is sovereignty. Sovereignty is thus accepted as an "essentially uncontested concept" (Walker 1990: 159; for different perspectives on sovereignty, see Bartelson 1995; Biersteker and Weber 1996; Hannum 1996; Hinsley 1986; Hoffman 1998; James 1986; Krasner 1999; Weber 1995), even though its usage in the context of Sino-Tibetan relations is recent (see Sperling 2004; see also Carlson 2005). And yet, the Tibet question remains an unsolved one in the international arena. A visible group of 
Tibetans and their supporters reject the status quo and argue that China does not have sovereignty over Tibet, and hence the current control of Tibet by China is a colonial, illegal occupation. This anti-Chinese sovereignty claim is multifaceted: History, religion, democracy, morality, development, decolonization, selfdetermination, international law, nationalism, transnationalism, human rights, and several other resources are marshaled to assert a historically distinctive identity for Tibet and Tibetans, with the implication that such an identity makes Tibet deserving of a distinct political identity, too.

Chinese control over Tibet can be understood through two different imperial trajectories-one Chinese and one Western. While the PRC focuses primarily on historical imperial ties to legitimize its control over Tibet, the fact that it uses the modern concept of sovereignty - a product of European universalization through imperialism and decolonization ${ }^{1}$ — shows the significance of the Western imperialist trajectory in the scripting of modern Tibet. Modern Chinese translation of Tibet's religio-political relations with the Mongols and Manchus, termed mchodyon (patron-priest), ${ }^{2}$ as a "domestic affair of China" was part of a wider development at the start of the twentieth century when nationalism emerged strongly. "China," imagined as a modern nation, ${ }^{3}$ maintained a schizophrenic attitude toward its imperial past, especially toward the Qing/Manchus. ${ }^{4}$ While the Manchus and other "barbarians" were held responsible for the decline of the "great" Han Chinese civilization and for failing to adjust and counter the rising European (and Japanese) powers, the territorial legacy of the Qing empire was seen as legitimate. The minoritization of Manchus, Mongols, Tibetans, Hui, and several other "nationalities" went hand in hand with the construction of "Han" identity as the leading force within multinational Chinese nationalism. ${ }^{5}$ In this nationalizing China, the traditionally fuzzy religio-political relations that

\footnotetext{
${ }^{1}$ The conflation of modern with European is not uncontested. This association is even more problematic when teleology is read into the shift from medieval to early modern to modern, with Europe as the natural leader of the engine of progress. For an interesting discussion of the different ways of being "early modern," see Sanjay Subrahmanyam (1997). Laura Hostetler (2001) offers an insight into the innovations going on in early modern China under the aegis of the Qing.

${ }^{2}$ On mchod-yon, see David M. Farquhar (1978), James L. Hevia (1995, 37-49), P. Christiaan Klieger (1992), and D. Seyfort Ruegg (1991). Despite the overarching frame of mchod-yon, relations between the Manchus (and before them the Mongols) and the Tibetan lamas were always in flux. See Mark C. Elliott (2001) and Peter C. Perdue (2005) for shifting attitudes in the Qing court and nationalizing reforms during late Qing times.

${ }^{3}$ For China's imagination as a modern nation, see Prasenjit Duara (1995); see also Ann Anagnost (1997). Interesting analyses of the relationship between nationalism, imperialism, and modernity can be found in Timothy Brook and Gregory Blue (1999), Duara (2003), Partha Chatterjee (1986) and Thongchai Winichakul (1994).

${ }^{4}$ For different perspectives on late Qing imperial rule and its significance for modern China, see Pamela Kyle Crossley (1999), Ping-ti Ho (1967, 1998), Elliott (2000), Magnus Fiskesjö (2006), Perdue (2005), and Evelyn S. Rawski (1996).

${ }^{5}$ For various arguments on national minorities in China, see Susan D. Blum (2002), Uradyn E. Bulag (2002), Frank Dikötter (1992), June Teufel Dreyer (1976), Dru C. Gladney (1994, 2004); Edward Friedman (1995), Thomas Herberer (1989), and Colin Mackerras (2003).
} 
marked Tibet's relations with the Qing court, and before that with the Mongols, were seen as anomalous, and sovereignty talk along absolutist European lines became dominant. This paper does not engage with the Chinese nationalist appropriation of Tibet as part of the "motherland" in the name of imperial legacy (see Anand n.d.); rather, it focuses on how Western ideas and practices, through the agency of British imperialism, facilitated the delegitimization of traditional Sino-Tibetan relations and ensured that Tibet's geopolitical identity became China's Tibet.

The most significant aspect of the British imperialist policy practiced in the first half of the twentieth century with regard to Tibet was the formula of "Chinese suzerainty/Tibetan autonomy." Inspired by Stephen D. Krasner's designation of sovereignty as "organised hypocrisy" (1999), I term this formulaic interpretation of Sino-Tibetan relations strategic hypocrisy. As we will see in this paper, China rejected the formula but adopted the European concept of sovereignty and asserted it as the sole marker of Sino-Tibetan relations, etching it indelibly through the 1951 Seventeen-Point Agreement. Tibet entered the modern political imaginary thus. In the rest of the paper, I focus on the role of the British imperial perspective in the creation of this contemporary notion of "Tibet" as a geopolitical entity through hitherto unemphasized or neglected British policy documents and expedition reports, read with the critical eye of a multidisciplinary "anthropologist." A reified notion of sovereignty is thus challenged as ahistorical, opening up a space for imagining sovereignty differently and multiply.

\section{BRITISH IMPERIALISM AND TibeT}

The Western imperial scripting of Tibet occurred through the agency of British imperialism. We can study this scripting in four different phases. The first phase (1780-92) saw abortive efforts to establish relations with Tibet. The second phase (1792-1899) was marked by a lack of official interaction with Tibet, now imagined as the "forbidden land." In the third phase (19001904), there was a radical attempt to force modern international/imperial relations onto the hitherto "closed" Tibet, an attempt that was, in a sense, a flash in the pan, while at the same time, the forces it set rolling were irreversible. As a consequence, the fourth phase (1904-50) was marked by contradictions and saw the explicit use of European terminologies to define Tibet using the terms of suzerainty and autonomy. This formulaic etching of Tibet in the modern geopolitical imaginary, strategic hypocrisy, actively encouraged ambiguity and vagueness in line with the British imperial interests. The fourth phase ended with the complete Europeanization of the region as SinoTibetan relations were defined clearly in writing in terms of Chinese sovereignty in the 1951 Seventeen-Point Agreement. The PRC completed the European 
imperial scripting of Tibet by using a most effective weapon out of the European terminological armory-sovereignty.

\section{Phase I: Tibet as a Blank Space}

The significance of the representation of Tibet as a blank space, however, did not remain the same throughout pre-twentieth-century modern period. In the late eighteenth century, as the British were still at the start of their colonial phase in eastern India with a strong commercial ethos, the unknown quality of Tibet did not cause anxieties. In fact, it is interesting to note that Tibet aroused mere mild curiosity among a select few colonial officials, and even this curiosity was secondary to the possibility of Tibet as a trading and commercial partner. Two British officials were involved in this attempt to establish relationship with Tibet: George Bogle (1774-75 and a proposed dispatch in 1779) and Samuel Turner (1783). Tibet was seen as providing a possible backdoor entry to the mammoth of the "vast Chinese market" that was closed to Westerners.

However, Tibet was also seen as valuable on its own for trade and commercial purposes. When the missions failed in establishing diplomatic or commercial links with Tibet, it was not seen as significant. Thomas Manning's visit to Lhasa in 1811 (on his abortive attempt to go to Peking) did not arouse any interest in British India. Tibet as a blank space was not threatening. There was no urgency to define Tibet's political status or its relations with China. This does not mean that visitors did not comment on this aspect. For instance, in a letter dated September 30, 1775, Bogle clarifies Sino-Tibetan relations thus: "The Emperor of China is acknowledged [as] the sovereign of the country ... but the internal government of the country is committed entirely to natives ... the people of Thibet except at Lahasa, hardly feel the weight of a foreign yoke" (IOR 1768-84, 354, 397-98). In his account published in 1800, Turner observes,

The Tibetans do not, it is true, bend under the immediate authority of that Court, but its influence overawes them in all their proceedings, and produces a timidity and caution in their conduct, more suited to the character of subjects than allies. The jealousy with which they regard this interference of the Chinese, and their uneasiness under the yoke, though it rests so lightly upon them, was manifest, from the distant reserve with which they treated those officers and troops who came for no other purpose than to do honour to their High Priest. (1971, 253; emphasis added)

What is absent in these accounts of Bogle and Turner is the urge to define in precise terms. The use of the term "sovereignty" by Bogle did not reflect a recognition of China's absolute control over Tibet, for that clearly was absent. What comes out from both of these accounts are the following images of Tibet-it is a vibrant, 
"normal"6 place; the Chinese political supremacy is recognized; this supremacy does not translate into complete political dominance; Chinese influence is seen as "foreign," but, while there is unease, there is no strong sense of seeing this influence as foreign = unwanted vis-à-vis a notion of authentic Tibetan identity. There is no attempt by the Tibetans to portray a distinct Tibetan statehood in European terms, even to their British visitors. ${ }^{7}$ The statement of Tashi Lama (Panchen Lama/Teshoo Lama) to Bogle is interesting in this regard:

[W]e live in a cold hilly country, on one side of us is the Chinese Empire, on another the Great kingdom of Hindoostan of which I understand the Company is now master, and on a third the Russian Empire. We know nothing, and we do nothing but read and pray to god. One cannot tell who is chief of the country, one man says I am rajah, another says I am rajah, and third says I am rajah, but the Emperor of China is above all. (Younghusband Collection, MSS EUR/F197/105, 44)

\section{Phase II: Forbidden Tibet: Transformation from Curiosity to Anxiety}

The second phase (1792-1899) saw an absence of any formal interaction between British India and Tibet. Tibet's status as a blank space remained and, over time, evolved to arouse increasing curiosity, frustration, and provocation by the end of the nineteenth century. This was the period when Tibet was closed to the foreigners, especially Europeans. The usual practice is to trace it to a conscious policy by the Tibetan government in Lhasa to forbid travelers from coming into Tibet. This was after 1792, when the British refused to assist Tibetans against the Gurkha invasion from Nepal and Tibetans relied upon the Qing imperial court.

The second phase saw occasional unofficial travelers attempting to enter Tibet-with the exception of Manning, who went to Lhasa in 1811, most of them failed to go beyond the edge of Tibet or went to areas such as Ladakh or Sikkim that had some sort of tributary relations with Lhasa authority in Tibet (see Hervey 1853; Thomson 1852). But British India sought to acquire intelligence through Indian spies (usually called pundits; see Waller 1990). Attempts to open negotiations failed, as in 1885 when Tibetans turned back a British mission, refusing to recognize the Chinese issued passport. Tibet's blank space

\footnotetext{
${ }^{6}$ Unlike later images of Tibet as unique, the British saw the Tibetans just like any other people. In Bogle's view, the factor most favorable to friendly intercourse with Tibet was the commercial instincts of the Tibetans and the principle of self-interest. In a letter written in 1775, a year before Adam Smith's Wealth of Nations was published, Bogle opined that in commercial matters, "freedom and security is all that is required, merchants left to themselves, naturally discover the most proper manner of conducting their trade, and prompted by self interest carry it on to the greatest extent" (IOR 1768-84, 431).

${ }^{7}$ Luciano Petech's (1950) analysis of Tibetan texts from the period shows that these visits by British colonial officials were not seen as significant by the Tibetans.
} 
was now being populated with patchy information from the edge as well as the center (see Das 1902). Tibet was no longer important as a back door to China, as now the British (along with other Western powers) were successful in getting increasing access to China through wars and diplomacy.

The imperative to establish relations with Tibet came out of changes within the "knowledge-power" nexus that was British India. In the second half of the nineteenth century, cis-Himalayan regions influenced by Tibetan Buddhism and having some sort of symbolic-politico-religious relationship with central Tibet had come under the British influence. Having places within a sphere of influence that, in turn, had close subsidiary relations with a "blank space," a Tibet that was not yet a defined geopolitical entity, was seen as unacceptable by British India, the jewel in the crown of a quintessentially modern European empire. A desire to secure the cis-Himalayan region was an important imperative. This was also linked to new shifts in the concept of frontier (McKay 2003). Within the modern European conceptualization of sovereignty, states are "bounded communities." Boundaries are therefore what define the state. In the case of Tibet, and British India's border with Tibet, there was no clearly marked boundary. The will to map, the imperative to draw a distinct line, and the desire to have a bounded sense of identity and statehood-these were not present in Tibet (see McGranahan 2003; see also Klieger 1992; Norbu 2001). ${ }^{8}$

It should come as no surprise that George Curzon informed his audience at Oxford University in 1907 that "in Asiatic countries it would be true to say that demarcation has never taken place except under European pressure and by the intervention of European agents" (quoted in Lamb 1960, 210). In the second phase, British were not overly concerned about fixing boundaries so long as the cis-Himalayan states were secured. But this at the very least demanded an interaction with Tibet. Tibetans refused to have any dealings with British India. Assuming that the Chinese were still the "paramount power in Tibet" (Pundit A. K. in 1885, quoted in Bailey Collection, MSS EUR F157, 354), Britain negotiated trade agreements with China concerning Tibet. Yet again, there was no serious attempt to name Sino-Tibetan relations. For instance, Colman Macaulay in his report talks about Chinese power and supremacy but does not name it as suzerainty or sovereignty (IOR 1885).

Without challenging the right of Chinese to negotiate on their behalf and without making their case in terms of Tibetan sovereignty or independence, Tibetans simply refused to accept the agreements. The British blamed the

${ }^{8}$ Carole McGranahan identifies five key features that made the traditional Tibetan systems of statehood different from the modern European system: boundaries were locally determined and sanctioned; sovereignty and boundary were not coterminous; there were overlapping zones between polities; there was no imperative for an external ratification of rules; and there was a privileging of power relationships between territory and centre over territorial integrity $(2003,268)$. 
Tibetans refusal to interact with them on their essential "closed" nature, their parasitic priestly system that was fearful of losing privilege, the pressure of the Chinese overlords, and/or their irrational fear of British intentions (see Engelhardt 2002). This was a far cry from Bogle's assessment in 1774 of Lhasa as "the resort of strangers and the centre of communication between distant parts of the world" or Turner's comment in 1784 that "Thibet has from time immemorial been a resort of merchants" (IOR 1768-84, 359, 491). The attitudes of several Christian missionaries who sought to portray Tibet as a fortress and themselves as soldiers of God, and who spread stories about monastic rapacity and dominance in this heathen land, contributed to this negative portrayal of Tibet (see Bray 2001).

If one reads accounts from the period carefully (see, e.g., Das 1902, 193), it is clear that there was a visible fear of British imperialism inside Tibet. For instance, Macaulay was informed in 1885 that "all would go well if they [the Tibetans] did not fear that the English would take their country" (IOR 1885, 13; emphasis added). Even when this "fear of foreigners" was recognized, it was seen as irrational, backward, medieval, and hence wrong. The hegemonic imperial ethos prevented most commentators from accepting this fear as borne out of a legitimate understanding of the nature of modern Western imperialism. ${ }^{9}$

The Tibetan refusal to interact with the British was not accompanied by an articulation of independence in politico-legalistic terms. While this does not make sense within the modern Western mode of international relations, it can be understood within the traditional Tibetan worldview. A British Indian official narrates the view expressed by a monk at the start of the twentieth century: "[I]f the English entered Tibet, his bowl would be broken, meaning that the influence of his order would be destroyed, and its wealth, typified by the collections of food made from door to door in bowls, would be lost" (IOR 1904, 56). The religious vocabulary used to explain the fear of the British does not indicate its nonpolitical character. In fact, as Dawa Norbu argues, it was a "moral refusal to interact with new forces that violated the customary norms" borne out of a moral indignation, fear of colonialism, and military inability (1990, 38-39). One can distil this from Pundit A. K.'s observation, mentioned in a magazine article of 1885: "Evidently there was great fear of the English among the Tibetans and great fear of European maps" (Bailey Collection, MSS EUR/157/327). Tibetan understanding of the expansionary character of British imperialism was proven correct at the start of the twentieth century-or was it?

\footnotetext{
${ }^{9}$ For instance, later in 1904, when Tibetan monks informed him that they hated the Russians as much as they hated the British, Younghusband wrote in a letter, "My conclusions are that the monks are implacably hostile" (Younghusband Collection, MSS EUR/F197/105, 21). He did not see the hatred as stemming from a desire to avoid European imperialist rivalry-the "Great Game"-in Central Asia.
} 


\section{Phase III: British Invasion and the Emergence of Tibet in the Modern Geopolitical Imaginary}

The 1903-4 British mission was meant to rectify the vagueness and ambiguity that marked the political status of Tibet and to establish once and for all international relations between British India and Tibet. It was not so much about a mercenary appetite to open markets or a political plan to dominate and control but a politico-economic-cultural-epistemological desire to allay anxieties arising out of the geopolitical ambiguity of Tibet. But the actual impact of the mission was far more complicated and ambiguous than that envisioned by those directly involved. The invasion did allow a significant filling in of the blank space of Tibet in the British imperial imaginary. Whether or not Tibet interacted with British India was no longer of its choosing. In a scenario in which interaction with other modern/European international actors was the only means of being and becoming modern, Tibet was brought into modernity through the violence of invasion and diplomacy. Tibetans were forced to encounter the naked brute force of modern imperialism mostly dressed to impress. ${ }^{10}$ Whether they liked it or not, Tibet was represented as a buffer state and therefore became strategically important, not only for British India, but in the eyes of the Chinese state, which insisted on its incorporation into Chinese territory rather than serve as a buffer.

By 1900, all attempts by the British to establish some sort of communication with the Tibetan authority, both directly and through the Chinese, had failed. As an official document from the period puts it, Lhasa's "policy of exclusiveness" was tolerated because "anomalous and unfriendly as it ... [had] ... been, it carried with it no element of political or military danger" (IOR 1904, 153). But by 1900, this had changed. Tibet as a blank space acquired new meaning-it was unknown, vague, and open to all sorts of possibilities, and therefore it constituted a danger. This transformation in the significance of the unknown aspect of Tibet was a result of new ideas of the frontier and buffer state (see Bishop 1989; McKay 1997, 2003), Russian expansion in Central Asia, and Curzon's perceptions of Russian intrigue in Tibet.

The British decided to take the matter into their own hands, as previous attempts to deal with the Tibetans through China (hitherto seen as having "suzerainty" in Tibet) had clearly failed. Imperial action (a blending of negotiation and force) was required to firmly show Tibetans their place in the larger scheme of things - that is, as secondary to British imperial interest.

Initially, Curzon tried a policy of direct approach, sending letters to the Dalai Lama, but the letters were returned unopened. To rub salt into the wound, the British heard that the Dalai Lama had little hesitation in dispatching missions to

\footnotetext{
${ }^{10}$ Each member of the mission had to take with him his full-dress uniform as "ceremonial effect ... is an item never to be lightly passed over in dealings with Asiatics" (Younghusband 1910, 98). When signing the treaty in Potala Palace, Younghusband ordered everyone to dress in full regalia in order to impress the Tibetans.
} 
Russia through the Buriyat monk Dorjiev. This was the time of the "Great Game," an intense rivalry between British and Russians in Asia, and some "players" of this game, such as Curzon, pushed for a more active, confrontational policy (see Mehra 1979). In his famous dispatch of January 8, 1903, Curzon put his position in clear terms: "We regard the so-called suzerainty of China over Tibet as a constitutional fiction — a political affectation which has only been maintained because of its convenience to both parties" (IOR 1904, 154-55).

Curzon's dispatch was followed by strong advocacy of an armed mission. It was then that the Tibet missions were formed and sent (there were two missions, one after another when attempts to negotiate at the border region failed). This resulted in what was benignly called an "expedition," but it was, in practice, a military invasion of Tibet. The culmination was a treaty signed in Lhasa in 1904 seeking to establish British India’s relation with Tibet on a concrete basis. Though quite a few gains made here were soon given up by the British government in the interest of international diplomacy (the home government also showed a disapproval of Francis Younghusband for exceeding his briefs), this became a watershed event, especially because of its impact on China's attitude toward Tibet.

The home government was warning British India as early as April 28, 1904, while the British invasion was still going on, that "recent military incidents of advance are regarded by the Chinese Government, if not with satisfaction, as conducing to the recovery of the authority they have lost, at any rate with indifference"(IOR 1905a, 68; emphasis added). The invasion radically altered the Chinese perception of Tibet-the traditional loose political control characteristic of Qing imperial rule was no longer acceptable in nationalizing China (see Lamb 1960, 1986; Liming 1994; Tuttle 2005). The Qing court, regional governors, Nationalists, communists - all major actors in the rapidly changing China in the first part of the twentieth century-now conceptualized Tibet's position as strategic bulwark against hostile incursions from the south of the Himalayas. British invasion led to newfound concern among the governors of Sichuan regarding Tibet's vulnerability: "Tibet is a buttress on our national frontiersthe hand, as it were, which protects the face-and its prosperity or otherwise is of the most vital importance to China" (quoted in Tuttle 2005, 44). This framing of Tibet as strategic and as a weak link within the Chinese state is the main legacy of the Younghusband mission with serious ramifications even today. The new Chinese forward policy was even welcomed by some sections of the British Indian establishment, if a military report of 1910 is anything to go by:

It remains to be seen whether the awakening of China from her apathy in regard to Tibetan affairs will provide the leaders, the organisation, then training, and the aptitude for war which will transform the Tibetan army from an undisciplined mob of negligible value into a force which will command respect in future operations. (IOR 1910, 148) 
The placing of Tibet in the geopolitical imaginary with the 1903-4 invasion was closely linked with the dominant regimes of representation of Tibet. As the accounts of many participants of the Younghusband mission reveal (Candler 1905; Landon 1905; Millington 1905; Waddell 1905; Younghusband 1910), Tibet as a place combined the strategic and the mysterious. After all, as the Earl of Rosebery reminded the House of Lords around the time of the invasion, Tibet was "the most interesting country in the world" (Younghusband Collection, MSS EUR/F197/523). The most prevalent metaphor for the British invasion of Tibet was that of "unveiling" (Candler 1905). Powell Millington, who wrote his book as "a man in the street," described going to Lhasa as "assisting in drawing aside a purdah" and departure as the "show was over" (1905, 77, 199).

Stereotyping-especially negative toward Tibetan monks and patronizingly positive toward "ordinary" Tibetans_-served imperialism well. The massacre of Tibetans at Guru on March 31, 1904, was easily blamed on the malevolent "thorough-going obstructionist" (Younghusband Collection, MSS EUR/F197/ 105, 6) monks and superstitious Tibetan soldiers. We must liberate the ordinary natives from their brutal leaders - this sentiment can be seen in Younghusband's account when, after criticizing Tibetans for being crafty, immoral, overreligious, dirty, and lazy, he talks about the role of the British in providing enlightened guidance to ordinary Tibetans $(1910,321)$. In a letter written during the invasion, Younghusband expressed, "What was so aggravating was that a pleasant and genial people like the Tibetans wishing to debar the rest of the world from the pleasure of their society" (Younghusband Collection, MSS EUR/F197/105, 22; emphasis added). Of course, Tibetans had no right to prevent the British from enjoying Tibetan hospitality! While contemporary historians have emphasized the predatory nature of the mission (see Carrington 2003; French 2000), the mission is either ignored or whitewashed in most contemporary journalistic accounts of Tibet. ${ }^{11}$ What is clear is that the mission brought out into the open "the question of what exactly was Tibet, who had the final say in its affairs and what were its precise geographical limits" (Lamb 1986, 257).

\section{Phase IV: Strategic Hypocrisy and Cultivated Ambiguity}

Ironically, in their attempt to identify and define Tibet in order to have a clear basis for future international relations, the British efforts did not do away with the ambiguity over Tibet's status vis-à-vis China. The terms marshaled to categorize the Sino-Tibetan relationship were not sovereignty and independence but suzerainty and autonomy. The scripting of Tibet in terms of "Chinese suzerainty/ Tibetan autonomy" was a clever strategic move on the part of the British

\footnotetext{
${ }^{11}$ An article in The Times (from sometime in early 1980s) described the invasion thus: "The British decided to take a walk up to Tibet after attempts to talk to the Tibetans and warn them of the predatory nature of the Russians and Chinese had met with mountainous silence" (in Richardson Papers n.d., 34; emphasis added).
} 
(see Norbu 1990)_ a strategic hypocrisy. This shift suited the changing imperial interests of Britain in India, China, and Europe during the period. The ambiguity of Tibet was now an asset for the British imperial interest. Strategic hypocrisy allowed the British to deal with Tibet through China as the legitimate authority from 1905 onward and then after 1913 with Tibet as a de facto independent buffer state without having to offend China and other Western powers. It was privilege without responsibility. Travel to Tibet by foreigners was once again discouraged, if not outright prohibited, this time with the active connivance of British India. The viceroy's telegram dated December 23, 1904, affirmed the desirability of a relatively closed Tibet so as to keep "out foreign and Chinese concessionmongers" as well as to prevent "an inrush of British spectators in search of goldmine and other concessions" (IOR 1908b, 195).

In a strange turn away from the third phase at the start of the century, British preferred ambiguity over clarity, discouraged knowledge collection about Tibet unless it was officially sanctioned, and marshaled "Forbidden Tibet" in the aid of strategic hypocrisy. The British not only accepted nonmodern ambiguity in Sino-Tibetan relations but explicitly encouraged it through their use of "suzerainty" and "autonomy."

\section{De Facto and De Jure Chinese Control over Tibet (1905-12)}

Even when the Chinese, following in the wake of Younghusband mission, invaded Tibet and deposed the Dalai Lama, the British did not strongly call for respect of Tibetan autonomy. In fact, the aftermath of the Lhasa Convention was marked by conscious British imperial diplomacy to backtrack from Curzon's forward policy based on a notion of Russian threat and Chinese fictive suzerainty. Shifting alliances within Europe (Addy 1984, 79) meant that Russia became an ally and that Britain was committed to preventing the breakup of China.

After Younghusband received criticism from the home government, the original Lhasa Convention, signed on September 7, 1904, was modified and Britain persuaded China to sign an Adhesion Agreement in 1906, accepting the renegotiated terms. This act went back to the nineteenth-century practice of negotiating with Tibet through China and in effect reaffirmed Chinese control. Though no name was given to the Chinese control as late as 1906, it is clear from official documents of the period that the British government clearly accepted Chinese rule as suzerainty without insisting too much on Tibetan autonomy. While the British Indian government insisted that "both history and present experience prove that China does not possess full sovereignty in Tibet... . [and Tibet has] full contractual power," it requested that the British government persuade China to sign the Adhesion Agreement because it was "a most satisfactory one for China, her suzerainty in Thibet being fully recognized and her shortcomings in the past overlooked" (IOR 1905, 200, 165; emphasis added). 
China, experiencing the decline of the Qing court and the rise of nationalism, exercised its renewed authority through significant semantic changes in the agreements and treaties. The phrase "Tibetan Government" does not occur in the Adhesion Agreement "at the request of the Chinese" (IOR 1912a). No term was used to designate China’s status in Tibet. In fact, China never signed and ratified any treaty with Britain in the twentieth century that used "suzerainty" as a descriptive term for Chinese control over Tibet, consistently maintaining its sovereignty. As Eric Teichman, a British consular officer in eastern Tibet, narrates in his book, through these agreements, China obtained a "free hand in re-establishing and consolidating her position in Tibet without the possibility of foreign interference, and was thus enabled to keep the Tibetans for a few more years in a state of political and economic vassalage" (1922, 12).

It was a year later, in 1907, in an Anglo-Russian treaty that Chinese suzerainty was mentioned for the first time in writing: " "The Governments of Great Britain and Russia recognizing the suzerain rights of China in Tibet..." (quoted in Mehra 1979, 5). Tibet's status as autonomous under Chinese suzerainty-this was scripted under the authority of two Western imperial powers. Tibetans were never asked, nor were they allowed any voice. China, while affirming sovereignty rather than suzerainty, went on to be militarily active in Tibet.

The thirteenth Dalai Lama fled to India, but his requests for help from the British against Chinese military action in central Tibet fell on deaf ears. The British king replied to the Dalai Lama's 1911 request for intervention by saying that he "regrets that he is unable to interfere between him and his suzerain" (IOR 1908a, 54; emphasis added). It was clear that the British saw Tibet as an internal matter of China, so long as no other "foreign" power started interfering. China was not seen as a foreign power.

The Dalai Lama pleaded once more and possibly gave an insight into the Tibetan view on their traditional relations with China. His letter addressed to the king ${ }^{13}$ requests that Russian and British representatives be sent to Lhasa and states:

The reason for submitting this: Be pleased to remember that Tibet is related to China as a Priest to his Disciple.... Your Great Empire affords protection to the small kingdoms, so that the inhabitants live in peace. So, therefore, there has been, and will be, none other than Your Majesty who can afford protection to Tibet, and this protection we have resolutely determined to crave. (IOR 1913)

\footnotetext{
${ }^{12}$ The Chinese official stance on this is clear-the origin of so-called Tibetan independence is a product of Western imperialism. In fact, the 1907 Anglo-Russian Agreement for the first time changed Chinese sovereignty into "suzerainty" (see http://www.china.org.cn/e-white/tibet/9-2.htm). ${ }^{13}$ The letter to the British king also included a letter to the queen: "We request your Majesty to show your kindness towards us by not failing to move His Majesty the King to help us" (Dalai Lama, in IOR 1913).
} 
This letter shows a growing understanding of European modes of international relations and an attempt to get Western support against Chinese military dominance. But the British refused to help. It is interesting to study an exchange of notes among the branches of British Indian government as well as the home government over the viceroy's telegram to the Dalai Lama on June 11, 1912. Initially it was meant to have the following sentence expressing the "Desire of Government to see internal autonomy in Tibet under Chinese suzerainty but without Chinese interference and maintenance of cordial relations between Tibet and India." An official named R. Ritchie suggests that the "words 'without Chinese interference' are however somewhat unguarded," and another official (initialed H. L.) therefore proposes to amend the sentence- - "Desire of Govt is to see internal autonomy of Tibet under Chinese suzerainty without Chinese interference so long as treaty obligations are duly performed \& cordial relations preserved between Tibet \& India." He argues that this "formula has the further advantage of conveying a warning to the Dalai Lama of the consequences of disregarding the Convention" (IOR 1912c, 44, 43; emphasis added). The removal of "but" and addition of "so long as" suggests that Britain did not care about Tibet's status so long as its interests were met. Semantic changes in diplomacy had far-reaching significance for the defining of identities of geopolitical entities.

\section{De Facto Independent Tibet, De Jure (Un) Contested Chinese SUPREMACY (1913-51)}

The internal crisis within the Chinese state, with the collapse of the Qing empire, formation of the republic, and then the civil war within China, offered Tibet the opportunity to expel the Chinese army and to operate as a de facto independent state from 1913 to 1951. And yet, the Tibet that existed from 1913 to 1951 was not recognized as an independent state by any other state. British India, which at the turn of the century was seeking to define Tibet in clear geopolitical terms, now adopted a simple pragmatic opportunistic policy: Deal with Tibet as if it were independent but repeat the mantra of Chinese suzerainty so as not to offend China and other Western imperial powers suspicious of British aims in Tibet. All parties within China claimed sovereignty over Tibet. The Tibetans, except for some futile discussions about joining the League of Nations (Shakya 1985) and the Universal Postal Union (Fleck 1995) in the 1920s and more serious efforts in the form of a trade mission to the United Kingdom and the United States in 1948 (Shakya 1999), did not go out of their way to make a legal case for recognition of their independence from China.

The British portrayed themselves as a neutral arbitrator. This was exemplified during the tripartite Simla Talks in $1914,{ }^{14}$ which resulted in the signing of a firm

\footnotetext{
${ }^{14}$ Later in 1918, during the war between China and Tibet, Eric Teichman, a British consular officer, played a crucial role in drawing up the peace settlement (see Teichman 1922).
} 
convention between Great Britain and Tibet, in which the two partied agreed to the McMahon line as the border between India and Tibet. The disagreement between Tibet and China over the boundary of "Outer Tibet" (which was under the direct political control of the Lhasa government, as opposed to "Inner Tibet," which was under Chinese control) led to the withdrawal of China from the talks. The Simla Convention provided for Chinese suzerainty and Tibetan autonomy. Tibetans argued that because the Chinese had refused to sign, they would have to forego even nominal suzerainty. But there was no serious attempt to make this claim at any international level. Britain discouraged such efforts lest they provoke Chinese nationalist reaction: "The Chinese horse is very shy, \& has to be brought gently up to the obstacle!" (memorandum prepared for a debate in the House of Lords on July 28, 1914, in IOR 1912b, 5).

In response to the British Indian government's insistence on forcing China to accept Tibetan autonomy, Lord Broderick observes that

[T] he right of limitrophe States to have diplomatic relations, independently of their Suzerain Power, though no doubt it is historically true that it has been exercised by Thibet, is hardly one which it would be expedient for His Majesty's Government to urge, in view of the position which they claim in regard to the foreign regulations of Afghanistan. (IOR 1905, 4; emphasis added)

Tibet, "the Cinderella of the British Foreign Office," which never got a sympathetic hearing (Charles Bell, in Caroe Collection, MSS EUR/F203/18), would not be allowed to upset wider imperial calculations. China saw the convention as an unequal treaty imposed by British imperialists using Tibetans as their pawn. The British went on to stick to the suzerainty/autonomy formula while dealing with Tibet as an independent state but without committing to recognizing it as such.

During the Simla talks, the British aim was made clear-the only interest in Tibet was the security of British India and the frontier states. In fact, a document archived in the Asquith Papers at the Bodleian Library provides an interesting reading: The Chinese policy since the British left Lhasa [in 1904] has been "directed towards the consolidation of their position, and the conversion of their loose traditional suzerainty into a vigorous and effective sovereignty. In itself this might possibly have been a matter of indifference to us" had it not caused widespread disturbances and the "complete disappearance of the Tibetan Government with whom the Convention of 1904 was negotiated, and whose continued existence was required by that and subsequent instruments" (Asquith Papers 1913, 235; emphasis added). The lack of serious commitment to Tibetan autonomy, unless it threatened vital political interests, was evident throughout the 1913-1951 period of Tibetan de facto independence. 
That ambiguity was not only accepted as inevitable but was part of a conscious policy became clear once again in a 1930 communication from the home government to the viceroy of India: "[W]e do not wish to give Tibet idea either that we are opposed to ultimate settlement with China or that we are anxious to encourage her to throw off Chinese suzerainty" (IOR 1917, 4).

The strategic hypocrisy of British imperialism did not lead to a uniform set of policies (see McGranahan 2003; McKay 1997; Palace 2005). In fact, throughout the fourth phase, there were subtle (e.g., attempts made by the British Indian officials to encourage modernizers inside Tibet in 1920s; see Goldstein 1989) ${ }^{15}$ and sometime not so subtle (e.g., the 1914 Simla Convention) changes in policy. Pro-Tibet officials sought to emphasize Tibet's uniqueness to gain support for possible recognition of its independence (McKay 1997), while others adopted more cautionary note. ${ }^{16}$ In a secret memorandum dated May 5 , 1943, an argument is made to raise the profile of Tibet-the absorption of Tibet (by China) after the ongoing world war may be prevented if public opinion in the United Kingdom and the United States was "conditioned" to accept Tibet as largely autonomous and Tibetans as a distinct people who are "above all ... a charming people inhabiting a land full of romance and mystery" (IOR 1943-46, 181). Such efforts notwithstanding, the main principle behind the British policy remained unaltered-while China has suzerainty over Tibet (and direct rule over "Inner Tibet"), Tibet (rather, "Outer Tibet") is autonomous.

By the middle of 1930s, it was clear that the attempts to transform the Lamaist state into a modern quasi-nation-state had failed. Goldstein (1989) is right in putting the blame for this failure on the conservative monastic dominance of the state, but he underemphasizes the role of Britain. Similarly, the defense of Hugh Richardson (a colonial official known for his pro-Tibet sympathies) against Ngawang Thondup's letter criticizing the British for paving the way for Chinese suzerainty by defining Sino-Tibetan relations in terms of Chinese suzerainty is also telling-"the Chinese had never given up their claim over Tibet since 1728 and the policies of British did not make any difference" (Richardson Papers n.d., 175; emphasis added). While Richardson is correct about the Chinese claims, he is wrong in underplaying the British role. The semantic change introduced by the British to describe Sino-Tibetan relations was crucial in its Europeanization (Norbu 1990), a process that ended up fixing Tibet's

\footnotetext{
${ }^{15}$ For instance, Frank Ludlow introduced and encouraged football in Gyantse in Tibet to "instill the Tibetan youths with the moral sporting codes and ethos of the British Empire" and the "Tibetan colours he introduced of yellow and maroon [for the tams] had no local precedent" (McKay 2001, 96).

${ }^{16}$ British diplomatic officials in China often would caution against any activist foreign policy in Tibet so as to avoid offending China. For instance, Teichman wrote in a semi-official letter that the attitude of British Indian government "has been (and I presume still is) to secure a peaceful, friendly, and autonomous Tibet under Chinese suzerainty" (IOR 1928, 433).
} 
geopolitical identity in a manner not conducive to any claim for independent internationally recognized statehood.

Whatever modernizing efforts were encouraged by the local British Indian officials, such as Charles Bell, in transforming the Lamaist state into a modern state, there was always a conscious frowning upon of attempts to represent Tibet's separate identity at the international level. A secret letter from the British Indian government dated September 19, 1945, affirmed the policy that had been consistently followed over the last three decades-British must not intervene in Tibet's internal affairs because any modernization would challenge the monastic order and throw them into the hands of the Chinese as a "slow process of evolution is suited to Tibetan mentality and to our interests" (IOR 1943-46, 48; emphasis added). Political isolation of Tibet was convenient for Britain.

Britain did not want to be accused of dismembering China by encouraging Tibetan independence. The specter of a reactive annexationist policy by China was deployed to quash occasional efforts to give a more concrete geopolitical identity to Tibet that did not conform to the strategic hypocrisy. In April 1912 , a memorandum from John Jordan, the British representative in China, to his foreign secretary, warned that if the British did not insist upon the status quo (Chinese suzerainty/Tibetan autonomy) and went any further, "we may give other Powers opportunity of putting forward similar claims, and incur the charge of promoting a policy of dismemberment" (IOR 1912a, 152). Even as a regime perceived as hostile to the West (Communist PRC) threatened Tibet in 1950, the British ambassador to the United Nations advised the Foreign Office: "What we want to do is to create a situation which does not oblige us in practice to do anything about the Communist invasion of Tibet," and therefore the best position is to argue that the legal status of Tibet was extremely obscure (Shakya 1999, 55; emphasis added).

As British imperial interest wedded itself to the formulaic strategic hypocrisy of Chinese suzerainty/Tibetan autonomy, exoticized representations of Tibet did not remain merely esoteric or cultural. Unlike the negative representations of Tibet that were abundant during the third phase, there was a turn toward positive imagery of Tibetans. Ambiguity about Tibetans remained, but the Tibetan lamas were not despised the way they were at the start of the century, and Tibetan Buddhism was no longer seen as parasitic. This transformation of Tibet in the Western imagination was not related to changes within Tibet but to changes within the imperial West. As ideas of Western imperialism saw a slow but steady decline in the first half of the twentieth century and the confidence of British Empire was shaken thanks to the world wars and anticolonial nationalist movements, Tibet came to be invested with images, desires, and fantasies more easily than most other parts of the world. Escapism and fantasy characterized a number of writings about Tibet during the period. The ambiguity and hence the relative "placelessness" of Tibet in modern geopolitics acted as an easy recipient for Western 
representations of the absolute Other (Bishop 1989; see also Anand 2007), an Other that offered a different vision of the world but did not challenge West politically though anticolonial nationalism. The ambiguity of Tibet allowed for a depoliticized imagining (as in James Hilton's novel Lost Horizon, which introduced the myth of Shangri-La) that was no longer easy with decolonizing India or revolutionary China. Tibet could serve more easily as a "service society" and a "surrogate state" (Lopez 1998, 201, 203) by virtue of having not been clearly written into the space-time of grid of modern geopolitics.

The travel accounts from the period not only failed to "extinguish the myth of mysteriousness" (Cocker 1992, 219) but actually bolstered it. The uniqueness and salability of each individual travel book was contingent upon selling the image of Tibet as the unknown Other, and hence Tibet remained mysterious in the Western popular imagination. Sympathetic British Indian officials who did not buy into Tibet as exotica nevertheless did not destroy it; ${ }^{17}$ rather, they sought to use it as a resource to highlight a distinctive identity of Tibet (McKay 1997, 207). A most illustrative example of the (attempted) use of exoticized representation for political purpose is a secret (now declassified) document from 1943 on the "Status of Tibet and Publicity" (IOR 1943-46). The document consists of notes exchanged on the possible use of the image of Tibet. It also reveals differences over the fate of Tibet. Responding to a memorandum suggesting the use of the "glamor" of Tibet to raise Tibet's international profile, one letter cautions that apart from stirring Chinese counteraction, "the romantic may automatically provoke interest in the political” (IOR 1943-46, 179). It may compel Americans to

scent British propaganda, and to conclude that Tibet needed protection rather against British imperialism; or that it needed to be roused from its pathetic contentment and given the blessings of civilisation and reform, if not by China then by American business men (who would be ready on their own account to take any opportunities they saw) or missionaries. (IOR 1943-46, 170)

A further note agrees with this caution, suggesting that an attempt to raise the international profile of Tibet might have a "boomerang" effect in the United States: It would be taken up by American writers "as their own child," it might lead to "illadvised schemes" such as a demand for "presence of Tibetan representation at the peace conference," and American publicists might "cause offence to the Tibetans" or it might give "the Tibetans swelled head" - in any case, it would be a nuisance to the British Indian government (IOR 1943-46, 169; emphasis added). The last caution underlines the argument that the British did not want independence for

\footnotetext{
${ }^{17}$ In an undated account titled "The Hospitality of 'Forbidden' Tibet," Richardson includes a photo of a "tranquil scene in Lhasa - the most inaccessible city in Asia, but reminiscent of some quiet spot on the upper reaches of the Thames" (Richardson Collection, 199). Given that quite a few foreigners were living in Lhasa at the time, it is odd to repeat the cliché of forbidden Tibet.
} 
Tibet. Olaf Caroe, an official later associated with pro-Tibet sentiments, informed the enthusiastic officers on October 13, 1943, that even though "a sustained policy of "glamourizing" Tibet would not get department agreement," there "is advantage in maintaining the mystery of this nomanland as long as we can. It helps to sustain the buffer" (IOR 1943-46, 166).

\section{The Coupling of Sovereignty and Statehood}

Tibetans only started making serious attempts to gain international recognition as a state in 1948-50, but they were either ignored or undermined by the British, who no longer ruled India. Newly decolonized India, as the successor state to British India, asserted its sphere of influence over culturally Tibetan areas in northeast and northern India by treating the Simla Agreement and McMahon line as legitimate. But it saw extraterritorial rights over Tibet, something won over by the British during 1930s, as part of imperial legacy that could be easily given up. In 1954, India accepted the position that Tibet is an "integral" part of China. Tibet as a multicoded yet ambiguous space was now an avoidable irritant as India sought to make its own mark as a postcolonial state and have friendly relations with China. Similarly, Tibet was a liability for the British, who no longer needed even the strategic hypocrisy. However, not only did the British ignore Tibetan efforts to acquire international personality in 1948-49, they actively discouraged any other state from encouraging them. Almost pre-staging the replacement of suzerainty with the discourse of sovereignty, the British government clarified its policy on the status of Tibet immediately after the end of World War II thus:

Before the fall of the Manchu Empire in 1912, Tibet was under Chinese sovereignty. In that year she broke away and although she has maintained her independence ever since (subject to her recognition of Chinese suzerainty) the Chinese have in recent years shown an increasing tendency to claim sovereignty over the country. (IOR 1945-46, 3)

What this suggests is that China had sovereignty over Tibet until 1912, and then suzerainty from 1913 on, and it was asserting its sovereignty again. This interpretation of pre-1912 Sino-Tibetan historical relations would have surprised most previous as well as contemporary British imperial officials, who saw Chinese dominance in vague nominal nonsovereign terms.

Let us also notice the shift in the use of the key term from a Coalition War Cabinet Conclusion dated July 7, 1943, to a secret document of Cabinet Far Eastern Civil Planning Unit dated November 5, 1945. The former (1943) mentions that it was agreed

(a) that they should avoid committing H.M.G. to recognition of Chinese suzerainty over Tibet unconditionally and independently of Chinese 
acceptance of Tibetan autonomy (b) that, if necessary, a warning should be added that, if the Chinese attempted to upset Tibetan autonomy, H.M.G. would have to consider withdrawal of their recognition of Chinese suzerainty. (IOR 1943-46, 62)

The latter document (1945) followed the wording closely with one subtle yet significant change:

[T]he British representatives should_-(a) avoid committing His Majesty’s Government to recognition of Chinese sovereignty over Tibet unconditionally and independently of Chinese acceptance of Tibetan autonomy and (b) if necessary add a warning that if the Chinese attempted to upset Tibetan autonomy His Majesty’s Government would have to consider withdrawal of their recognition of Chinese suzerainty. (IOR 1943-46, 57)

The semantic change from suzerainty to sovereignty made by the British in their internal official documents occurred well before any serious Chinese attempt to reassert political and military control over Tibet.

As the Chinese regained control over Tibet and the Lamaist state was absorbed into the PRC, the formula of strategic hypocrisy, Chinese suzerainty/ Tibetan autonomy, was no longer in the running. A confidential Foreign Office memorandum of 1948 makes clear that because the main rationale for this formula was the security of the Indian empire, after India's independence, it was redundant and therefore "it may seem no longer necessary for His Majesty’s Government actively to support Tibetan autonomy” (IOR 1946-49). Occasionally, Britain paid lip service to it, as during the 1961 General Assembly resolution. But the decolonizing world did not have any room for ambiguous suzerainty as the sovereignty talk acquired an unchallengeable hegemony. Britain silently and conveniently dropped the formula that it had been adhering to for the last half century and that it had been instrumental in inscribing through various international treaties. The European imperial scripting of Tibet was complete with China claiming sovereignty in 1951.

What is remarkable about Tibet is the fact that while British imperial policy encouraged Tibetan statehood, it also bolstered Chinese claims to sovereignty. This decoupling of statehood and sovereignty was made possible by the peculiar and ambiguous status of Tibet fostered by conscious British imperial policy. The British clearly recognized the distinct statehood of Tibet throughout the first half of the twentieth century, and especially after 1913, not only in practice, but in rhetoric, too. For instance, in a cabinet memorandum relating to Tibet, 1912-14, the foreign secretary informs, "though we recognised Chinese suzerainty over Thibet, Thibet ought to remain an autonomous State between India and China" (Viscount Harcourt Papers n.d., 62). But this statehood was accepted without the use of the discourse of sovereignty, a practice commonly followed in the "uncivilized" parts of the world by Western imperialists (Strang 1996). This unnatural 
decoupling could not work in the decolonizing world, where the principle of sovereign statehood became the only way of being political and international.

\section{Conclusion}

The (European) imperial scripting of Tibet reveals the West's constitutive role in the framing of the Tibet question. It shows that the intractability of political problems in the postcolonial world is attributable neither to long-standing historical animosity nor to essential cultural differences. The West as a source of universalized ideas and as an actor is implicated in the scripting of such political problems. Imperialism is not only a matter of historical curiosity but also integral to contemporary international politics. Non-Western actors have not been merely passive recipient of European ideas or easy victims. They have appropriated Western ideas to transform their own sense of political community. Tradition's utility is as a resource for buttressing claims to modern statehood. Those like the Tibetans, who have lost out at the crucial moment of decolonization, find it hard to make claims to be recognized as a separate nation-state unless there is a breakup of an existing state or powerful states support secession from existing states. In the case of Tibet, neither of these conditions is in the realm of possibility, leaving the diasporic Tibetans under the Dalai Lama with little room for maneuver. What they need to keep in mind is that the West, through its imperial scripting of modern Tibet, has been an ally of China in the latter's appropriation of the modern vocabulary of sovereignty.

\section{Acknowledgments}

Archival research in the British Library, Oxford, and Cambridge was made possible through grants from the British Academy and Chiang Ching-Kuo Foundation. I am grateful for comments and suggestions received at seminars in China, India, the United Kingdom, and the United States from some people I know-especially Robbie Barnett, Christiaan Klieger, Dan Lindley, and Lobsang Sangay-and many whom I do not by name. Thanks to Nitasha Kaul for her critical comments and support.

\section{List of References}

Addy, Premen. 1984. Tibet on the Imperial Chessboard: The Making of British Policy towards Lhasa, 1899-1925. Calcutta: Academic.

Anagnost, Ann. 1997. National Past-Times: Narrative, Representation, and Power in Modern China. Durham, N.C.: Duke University Press.

Anand, Dibyesh. 2007. Geopolitical Exotica: Tibet in Western Imagination. Minneapolis: University of Minnesota Press.

—. 2008. Tibet: A Victim of Geopolitics. New Delhi: Routledge. 
n.d. Representing China’s Tibet. Unpublished manuscript.

Asquith, H.H. Papers. 1913. Bodleian Library, Modern Political Papers, MS Asquith 93.

Bailey Collection. n.d. British Library, India Office Records, European Manuscripts, MSS EUR/F157.

Bartelson, Jens. 1995. Genealogy of Sovereignty. Cambridge: Cambridge University Press.

Biersteker, Thomas J, and Cynthia Weber, , eds. 1996. State Sovereignty as Social Construct. Cambridge: Cambridge University Press.

Bishop, Peter. 1989. The Myth of Shangri-La: Tibet, Travel Writing, and the Western Creation of a Sacred Landscape. Berkeley and Los Angeles: University of California Press.

—. 1993. Dreams of Power: Tibetan Buddhism and the Western Imagination. London: Athlone Press.

Blum, Susan D. 2002. "Margins and Centers: A Decade of Publishing on China’s Ethnic Minorities." Journal of Asian Studies 61 (4): 1287-1310.

Bray, John. 2001. "Nineteenth- and Early Twentieth-Century Missionary Images of Tibet." In Imagining Tibet: Perceptions, Projections, and Fantasies, ed. Thierry Dodin and Heinz Räther, 21-45. Boston: Wisdom Publications.

Brook, Timothy, and Gregory Blue, eds. 1999. China and Historical Capitalism: Genealogies of Sinological Knowledge. Cambridge: Cambridge University Press.

Bulag, Uradyn E. 2002. The Mongols at China's Edge: History and the Politics of National Unity. Lanham, Md.: Rowman \& Littlefield.

Candler, Edmund. 1905. Unveiling of Lhasa. London: Edward Arnold.

Carlson, Allen. 2005. Unifying China, Integrating with the World: Securing Chinese Sovereignty in the Reform Era. Stanford, Calif.: Stanford University Press.

Caroe Collection. n.d. British Library, India Office Records, European Manuscripts, MSS EUR/F203/18.

Carrington, Michael. 2003. "Officers, Gentlemen and Thieves: The Looting of Monasteries during the 1903/4 Younghusband Mission to Tibet." Modern Asian Studies 37 (1): 81-109.

Chatterjee, Partha. 1986. Nationalist Thought and the Colonial World: A Derivative Discourse. London: Zed.

Cocker, Mark. 1992. Loneliness and Time: The Story of British Travel Writing. London: Secker and Warburg.

Crossley, Pamela Kyle. 1999. A Transhucent Mirror: History and Identity in Qing Imperial Ideology. Berkeley and Los Angeles: University of California Press.

Das, Sarat Chandra. 1902. Journey to Lhasa and Central Tibet. London: John Murray. Dikötter, Frank. 1992. The Discourse of Race in Modern China. London: C. Hurst.

Dodin, Thierry, and Heinz Räther, , eds. 2001. Imagining Tibet: Perceptions, Projections, and Fantasies. Boston: Wisdom Publications.

Dreyer, June Teufel. 1976. China's Forty Millions: Minority Nationalities and National Integration in the People's Republic of China. Cambridge, Mass.: Harvard University Press.

Duara, Prasenjit. 1995. Rescuing History from the Nation: Questioning Narratives of Modern China. Chicago: University of Chicago Press.

. 2003. Sovereignty and Authenticity: Manchukuo and the East Asian Modern. Lanham, Md.: Rowman \& Littlefield.

Elliott, Mark C. 2000. "The Limits of Tartary: Manchuria in Imperial and National Geographies.” Journal of Asian Studies 59 (3): 603-46. 
—. 2001. The Manchu Way: The Eight Banners and Ethnic Identity in Late Imperial China. Stanford, Calif.: Stanford University Press.

Engelhardt, Isrun. 2002. "The Closing of the Gates: Tibetan-European Relations at the End of the Eighteenth Century.” In Tibet, Past and Present, ed. Henk Blezer, 229-46. Leiden: Brill.

Farquhar, David M. 1978. "Emperor as Bodhisattva in the Governance of the Ch'ing Empire." Harvard Journal of Asiatic Studies 38 (1): 5-34.

Fiskesjö, Magnus. 2006. "Rescuing the Empire: Chinese Nation-Building in the Twentieth Century." European Journal of East Asian Studies 5 (1): 15-44.

Fleck, G. 1995. “Tibet and the Universal Postal Union.” Tibetan Review 30 (3): 16-18. French, Patrick. 2000. Younghusband: The Last Great Imperial Adventurer. London: Flamingo.

Friedman, Edward, ed. 1995. National Identity and Democratic Prospects in Socialist China. Armonk, N.Y.: M. E. Sharpe.

Gladney, Dru C. 1994. "Representing Nationality in China: Refiguring Majority/Minority Identities." Journal of Asian Studies 53 (1): 92-123.

—. 2004. Dislocating China: Muslims, Minorities, and Other Subaltern Subjects. Chicago: University of Chicago Press.

Goldstein, Melvyn C. 1995. "Tibet, China and the United States: Reflections on the Tibet Question." Occasional paper, Atlantic Council of the United States. http://www.columbia.edu/itc/ealac/barnett/pdfs/link4-goldstn.pdf [accessed September 22, 2008].

Goldstein, Melvyn C, with Gelek Rimpoche. 1989. A History of Modern Tibet, 19131951: The Demise of the Lamaist State. Berkeley and Los Angeles: University of California Press.

Hannum, Hurst. 1996. Autonomy, Sovereignty, and Self-Determination: The Accommodation of Conflicting Rights. Rev. ed. Philadelphia: University of Pennsylvania Press.

Harcourt, Lewis (Viscount), Papers. n.d. Bodleian Library, Modern Political Papers, MS Harcourt 589.

Herberer, Thomas. 1989. China and Its National Minorities: Autonomy or Assimilation? London: Routledge.

Hervey, Mrs 1853. The Adventures of a Lady in Tartary, Thibet, China, \& Kashmir. London: Hope and Co.

Hevia, James L. 1995. Cherishing Men from Afar: Qing Guest Ritual and the Macartney Embassy of 1793. Durham, N.C.: Duke University Press.

Hinsley, F. H. 1986. Sovereignty. 2nd ed. Cambridge: Cambridge University Press.

Ho, Ping-Ti. 1967. “The Significance of the Ch'ing Period in Chinese History." Journal of Asian Studies 26 (2): 189-95.

—. 1998. "In Defense of Sinicization: A Rebuttal of Evelyn Rawski's 'Reenvisioning the Qing." Journal of Asian Studies 57 (1): 123-55.

Hoffman, John. 1998. Sovereignty. Minneapolis: University of Minnesota Press.

Hostetler, Laura. 2001. Qing Colonial Enterprise: Ethnography and Cartography in Early Modern China. Chicago: University of Chicago Press.

India Office Records (IOR). 1768-84. “Correspondence and Reports Relating to Assam, Bhutan, China, Lhasa, Nepal and Tibet from George Bogle and Lt Samuel Turner, 16 Mar 1768-2 Mar 1784.” British Library, Home Office Miscellaneous Series, H/219.

. 1885. "Report of a Mission to Sikkim and the Tibetan Frontier with a Memorandum on our Relations with Tibet by Colman Macaulay." British Library, Political and Secret Department Miscellaneous Records, L/P\&S/20/D129. 
. 1904. "Papers Relating to Tibet." British Library, V/4 Parliamentary Papers HoC, V Cd. 1920.

. 1905a. "Further Correspondence Respecting the Affairs of Tibet, Part III." British Library, Political and Secret Miscellaneous Records, L/P\&S/19/FO Confidential 8415 .

—. 1905b. "Further Correspondence Respecting the Affairs of Tibet, Part IV." British Library, Political and Secret Miscellaneous Records, L/P\&S/19/FO Confidential 8509.

—. 1905c. "Further Correspondence Respecting the Affairs of Tibet, Part V." British Library, Political and Secret Miscellaneous Records, L/P\&S/19/FO Confidential 8510.

. 1908a. "Tibet: The Dalai Lama, 1904-13." British Library, Political and Secret Separate (Subject) Files, L/P\&S/10/147.

_ . 1908b. "Tibet: Infringement of Treaties, Frontier Questions, Chinese Troops, 1904-13." British Library, Political and Secret Separate (Subject) Files, L/P\&S/ 10/150 2750 5-7.

—. 1910. "Military Report on Tibet." British Library, Military Department and War Staff Records, L/MIL/17/14/92.

_ 1912a. "China and Tibet, 1912." British Library, Political and Secret Separate (Subject) Files, L/P\&S/10/265.

. 1912b. "Tibet: Parliamentary Questions, Apr-Jul 1912.” British Library, Political and Secret Annual Files, L/P\&S/11/15 File P 1701.

. 1912c. "Tibet: Question of Direct Communications." British Library, Political and Secret Annual Files, L/P\&S/11/24.

1913. "Tibet: Exchange of Presents between the Dalai Lama and King George V, May 1913-Sep 1914.” British Library, Political and Secret Annual Files, L/P\&S/11/ 64 File P 3937.

— 1917. "Tibet: Proposed Revision of 1914 Convention, 1922-30.” British Library, Political and Secret Separate (Subject) Files, L/P\&S/10/718.

—. 1928. "Tibet: Anti-British Propaganda at Chungking." British Library, Political and Secret Annual Files, L/P\&S/10/1228.

. 1943-46. "Status of Tibet: Publicity by China and HMG, May 1943-June 1946." British Library, Political (External) Files and Collections, L/P\&S/12/4196.

— . 1945-46. "Status of Tibet: HMG's Policy, Oct 1945-Feb 1946." British Library, Political (External) Files and Collections, L/P\&S/12/4195A.

_ . 1946-49. "Status of Tibet: HMG's Policy, Feb 1946-Feb 1949." British Library, Political (External) Files and Collections, L/P\&S/12/4195B.

James, Alan. 1986. Sovereign Statehood: The Basis of International Society. London: Allen \& Unwin.

Klieger, P. Christiann. 1992. Tibetan Nationalism: The Role of Patronage in the Accomplishment of National Identity. Meerut: Archana Publications.

_ 1997. "Shangri-La and Hyperreality: A Collision in Tibetan Refugee Expression." In Tibetan Culture in the Diaspora, ed. Frank J Korom. Vienna: Verlag der Österreichischen Akademie der Wissenschaften.

Krasner, Stephen D. 1999. Sovereignty: Organized Hypocrisy. Princeton, N.J.: Princeton University Press.

Lamb, Alastair. 1960. Britain and Chinese Central Asia: The Road to Lhasa, 1767 to 1905. London: Routledge and Paul.

—. 1986. British India and Tibet, 1766-1910. Rev. ed. London: Routledge \& Kegan Paul. 
Landon, Perceval. 1905. Lhasa: An Account of the Country and People of Central Tibet and of the Progress of the Mission Sent there by the English Government in the Year 1903-04. London: Hurst and Blackett.

Liming, S. 1994. "The Younghusband Expedition and China’s Policy towards Tibet, 19031904." In Tibetan Studies: Proceedings of the 6th Seminar of the International Association for Tibetan Studies, ed. Per Kvaerne, 59-68. Oslo: Institute for Comparative Research in Human Culture.

Lopez, Donald S., Jr. 1998. Prisoners of Shangri-La: Tibetan Buddhism and the West. Chicago: University of Chicago Press.

Mackerras, Colin. 2003. China's Ethnic Minorities and Globalisation. London: RoutledgeCurzon.

McGranahan, Carole. 2003. "Empire and the Status of Tibet: British, Chinese, and Tibetan Negotiations, 1913-1934." In The History of Tibet, vol. 3, The Modern Period: 1895-1959: The Encounter with Modernity, ed. Alex McKay, 267-95. London: RoutledgeCurzon.

McKay, Alex. 1997. Tibet and the British Raj: The Frontier Cadre, 1904-1947. Richmond: Curzon Press.

—. 2001. “Kicking the Buddha's Head': India, Tibet and Footballing Colonialism.” In Soccer in South Asia, ed. Paul Dimeo and James Mills, 89-104. London: Frank Cass.

Lamb, Alastair. 2003. "19th Century British Expansion of the Indo-Tibetan Frontier: A Forward Perspective." Tibet Journal 28 (4): 61-76.

Menra, Parshotam. 1979. The North-Eastern Frontier: A Documentary Study of the Internecine Rivalry between India, Tibet and China. Vol. 1, 1906-1914. Delhi: Oxford University Press.

Millington, Powell. 1905. To Lhassa at Last. London: Smith, Elder.

Norbu, Dawa. 1990. “The Europeanization of Sino-Tibetan Relations, 1775-1907: The Genesis of Chinese 'Suzerainty' and Tibetan 'Autonomy.”' Tibet Journal 15 (4): $28-74$.

- 2001. China's Tibet Policy. London: Curzon Press.

Palace, Wendy. 2005. The British Empire and Tibet, 1900-1922. London: RoutledgeCurzon.

Perdue, Peter C. 2005. China Marches West: The Qing Conquest of Central Eurasia. Cambridge, Mass.: Belknap Press of Harvard University Press.

Petech, Luciano. 1950. "The Mission of Bogle and Turner according to the Tibetan Texts." T'oung Pao, 2s, 39: 330-46.

Rawski, Evelyn S. 1996. "Reenvisioning the Qing: The Significance of the Qing Period in Chinese History.” Journal of Asian Studies 55 (4): 829-50.

Richardson, Hugh, Papers. n.d. Bodleian Library, Department of Oriental Collections, MS Or. Richardson 35.

RuegG, D. Seyfort. 1991. "Mchod yon, yon mchod, and mchod gnas/yon gnas: On the Historiography and Semantics of a Tibetan Religio-Social and Religio-Political Concept." In Tibetan History and Language, ed. Ernst Steinkellner, 329-51. Vienna: Arbeitskreis für Tibetische und Buddhistische Studien.

Sautman, Barry, and June Teufel Dreyer, eds. 2006. Contemporary Tibet: Politics, Development, and Society in a Disputed Region. Armonk, N.Y.: M.E. Sharpe.

Shakya, Tsering. 1985. “Tibet and the League of Nations." Tibet Journal 10 (3): 48-56. . 1999. The Dragon in the Land of Snows: A History of Modern Tibet since 1947. London: Pimlico. 
Sperling, Elliot. 2004. The Tibet-China Conflict: History and Polemics. Washington, D.C.: East-West Center. http://www.eastwestcenter.org/fileadmin/stored/pdfs/ PS007.pdf [accessed September 22, 2008].

Subrahmanyam, Sanjay. 1997. "Connected Histories: Notes Towards a Reconfiguration of Early Modern Eurasia." Modern Asian Studies 31 (3): 735-62.

Teichman, Eric. 1922. Travels of a Consular Officer in Eastern Tibet. Cambridge: Cambridge University Press.

Thomson, Thomas. 1852. Western Himalaya and Tibet: A Narrative of a Journey through the Mountains of Northern India during the Year 1847-48. London: Reeve and Co.

Thongchai, Winichakul. 1994. Siam Mapped. Honolulu: University of Hawai'i Press.

Turner, Samuel. 1971. An Account of an Embassy to the Court of the Teshoo Lama in Tibet. New Delhi: Manjushri.

TutTle, Gray. 2005. Tibetan Buddhists in the Making of Modern China. New York: Columbia University Press.

WADDELL, L. A. 1905. Lhasa and Its Mysteries: With a Record of the Expedition of 19031904. London: John Murray.

Walker, R. B. J. 1990. “Sovereignty, Identity, Community: Reflections on the Horizons of Contemporary Political Practice.” In Contending Sovereignties: Redefining Political Community, ed. R. B. J Walker and Saul H Mendlovitz, 159-68. Boulder, Colo.: Lynne Rienner.

Waller, Derek. 1990. The Pundits: British Exploration of Tibet and Central Asia. Lexington: University Press of Kentucky.

Weber, Cynthia. 1995. Simulating Sovereignty: Intervention, the State, and Symbolic Exchange. Cambridge: Cambridge University Press.

Younghusband Collection. n.d. British Library, India Office Records, European Manuscripts, MSS EUR/F197.

Younghusband, Francis. 1910. India and Tibet: A History of the Relations Which Have Subsisted between the Two Countries from the Time of Warren Hastings to 1910; with a Particular Account of the Mission to Lhasa of 1904. London: John Murray. 